Frederik Kortlandt

\title{
THE GERMANIC SIXTH CLASS OF STRONG VERBS
}

1. In an earlier article (1992), I argued that Go. nam, nemun 'took', gaf, gebun 'gave', -et, etun 'ate' represent original *ōme, *ēmunp, *öe, *ēbunp, *ōte, *ētunp. Similarly, Go. -on 'breathed', ON. $\sigma l$ 'nourished', $\sigma k$ 'traveled' continue reduplicated preterits *ōn-, * $\bar{o}-$-, *ok-, where the long vowel arose from the merger of earlier $*^{-} \delta^{-}$in the singular and $*_{\bar{a}}$ - in the plural. This development eliminated the apophonic distinction between sg. and pl. forms in these preterits and provoked the merger of the type with the root aorist Go. stop, stopun, OE. stōd, stōdon 'stood'. This root aorist correlates with a $d$ present with nasal infix stand-. Another verb which apparently combines a root aorist with a $d$-present is Go. -hlapan, OE. hladan 'to load', cf. Lith. klóti, Slavic klad-. Thus, the sixth class of strong verbs seems to have originated as a distinct category from the merger of the reduplicated preterits of IE. *an-, *al-, *ak- with the root aorists of IE. ${ }^{*} s t \overline{-}$ - and $* k l \overline{\alpha_{-}}{ }^{1}$ Since the resulting class lacked the usual apophonic difference between sg. and pl. forms in the preterit, it provided a convenient model for analogical extension to verbs with a present stem of the types $C a R$ - and $C a C$. This raises a number of questions.

2. First of all, we may wonder why *ar- 'plow' did not join the sixth class of strong verbs but developed a seventh class reduplicated preterit *ear- in Old High German and joined the first class of weak verbs in the other North and West Germanic languages. As I pointed out already (1992:103), I think that *ear- replaced an earlier root aorist *ar- at a recent stage because the je-present of this verb in Celtic, Germanic, Baltic and Slavic suggests that the root had aorist meaning in the northern IE. languages. We must therefore ask ourselves if the vocalism in the preterit of the other Germanic je-presents points to an earlier aorist or to a perfect formation. 
In Gothic, six out of the seven verbs with a je-present and a strong preterit belong to the sixth class: bidjan 'to pray', hafjan 'to lift', hlahjan 'to laugh', frapjan 'to understand', skapjan 'to harm', gaskapjan 'to create', wahsjan 'to grow'. It appears that strong verbs with a root in a velar stop and a je-present created a weak preterit on the basis of the past participle in *-htas (Kortlandt 1989:107): bugjan 'to buy', waurkjan 'to work', brukjan 'to use', pugkjan 'to believe', preterit bauhta, waurhta, bruhta, buhta. The earlier strong preterit is still evident from OE. brēac 'used' and warhte beside worhte 'worked', also pohte, Go. pahta 'thought', which gave rise to a secondary present ${ }^{*}$ bankeje- in Proto-Germanic times already. The new formation gave way to a regular first weak class preterit in the case of sokjan 'to seek' and faurhtjan 'to fear': sokida 'sought', faurhtidedun 'they feared', OE. sōhte, OHG. suohta, forahtun. The vocalism of $\mathrm{OE}$. brēac, warhte, pōhte points to an earlier perfect formation while sohte is ambiguous because it represents the IE. root *sāg-. ${ }^{2}$

From an Indo-European point of view, Go. hafjan, bugjan, waurkjan, pugkjan, faurhtjan, and paursjan 'to thirst' (cf. Schmid 1963:97) belong to the flexion type of Latin capio 'I seize' with a zero grade root vowel and a $y a$-present in Indo-Iranian. The same probably holds for wahsjan 'to grow', hazjan 'to praise', and *-safjan 'to perceive'. ${ }^{3}$ The verbs bugjan and sokjan can hardly be separated from biugan 'to bend' and sakan 'to quarrel', respectively. If sokjan is a secondary formation on the basis of the preterit stem * $s o k$-, it is possible that sakan had a je-present at an earlier stage and that we may compare the relation between the two verbs with that between bagkjan and pugkjan. This is in accordance with the fact that Old Irish saigid 'seeks' has a je-present which may be identified with the flexion of Latin capio (Thurneysen 1946:354). ${ }^{4}$

I conclude that there is no evidence for an original aorist among the sixth class preterits of $j e$-presents while all of them may represent earlier perfects. The vocalism of *hof and *so $k$ is ambiguous and the other verbs have an o-grade vowel. Since *ar- 'plow' did not develop a sixth class preterit, it is probable that *an-, *al-, *akjoined the sixth class at a recent stage and never served as a model for other verbs. It follows that we may regard the sixth class preterit 
as the regular outcome of the root aorist of IE. roots in $*_{-\bar{a}-}$, which may have served as a model long before the merger of $*^{-} a$ and $*^{-}$.

3. Chr. Stang has proposed for verbs with an o-grade present such as Lith. barti 'to scold', kalti 'to forge', málti 'to grind', kàsti 'to dig', OCS. brati 'to fight', klati 'to chop', bosti 'to stab', Latin fodio 'I dig', 'dass in diesen und anderen Verben mit den Bedeutungen "stechen, graben, schlagen, mahlen, zermalmen", wo neben $e$-stufigen auch $o$ stufige Formen vorkommen, die letzteren auf einen alten intensiven Präsenstypus mit $o$-stufiger Wurzelsilbe zurückgehen. Ich verweise auf skt. janghanti, (Präs. Part.) ghánighnat, die wegen der Erhaltung von $g h$ gegenüber $h$ in hâti einmal $o$-Stufe gehabt haben dürften' (1966:333, cf. already 1942:41-2). Here belong Gothic graban 'to dig', slahan 'to strike', malan 'to grind', ga-draban 'to hew out', gadragan 'to heap up', skaban 'to shave', swaran 'to swear', bwahan 'to wash', also faran 'to travel', cf. Dutch doorsteken 'to pierce, to cross', oversteken 'to cross'. ${ }^{5}$ It is clear that not all of these verbs are equally ancient. Since they constitute the bulk of the sixth class of strong verbs, we may regard this class as the reflex of the IE. intensives.

This raises the question of why the intensives followed the pattern of the root aorist in $*_{-}-\bar{a}$ - rather than the perfect ubiquitous in the formation of new preterits in the other strong verb classes. Since the intensives were a reduplicated o-grade formation, the perfect was not suitable as a clear model for an analogical preterit. As the original preterit of the intensives was an athematic imperfect, the root aorist was a much more likely candidate from the outset. Thus, I think that the imperfect took the place of an aorist at an early stage and came under the influence of the pattern which is reflected in OE. hladan 'to load', hlodon 'they loaded' after the merger of short ${ }^{*} a$ and ${ }^{*} o$. This model was not available to present stems of the type CaRC-, which joined the seventh class of strong verbs, e.g. Go. stautan 'to strike', skaidan 'to separate', blandan 'to mix'.

Apart from the o-grade thematic presents and zero grade jepresents, there are a few o-grade je-presents, viz. Go. frabjan, skabjan, hlahjan. ${ }^{6}$ These are probably old denominatives, cf. frapi 'understanding', skapis 'harm', and Russ. xóxot 'laughter', je-present xoxócet 'laughs'. They adopted the strong preterit as if they were 
primary verbs. Besides, there are three $o$-grade $j e$-presents of roots in *-w-, viz. ON. deyja 'to die', geyja 'to bark', kleyja 'to scratch', preterit $d \sigma, g \sigma, k l \sigma$. These may represent earlier intensives, cf. Lith. kauti 'to strike', where the root-final laryngeal yielded gemination in ON. heggua, OE. héawan, which therefore joined the seventh class of strong verbs.

\section{Cobetstraat 24}

NL-2313 KC Leiden

\section{Notes}

1. For the root aorist of IE. *dhe- see Kortlandt 1989:102.

2. Elsewhere I suggested that Go. brahta, OE. brohte 'brought' represents an original root aorist which adopted the pattern of a perfect formation (1992:106).

3. For wahsjan cf. Avestan $u x \breve{s y e i t i ~ ' g r o w s ' . ~ I ~ t h i n k ~ t h a t ~ t h e ~ f u l l ~ v o w e l ~}$ was generalized on the basis of the o-grade perfect stem. Though it is conceivable that the long vowel of the preterit wohs was taken from the reduplication syllable of "wowahs-, this is improbable for chronological reasons. The je-present was replaced by the regular thematic flexion in North and West Germanic for differentiation from the causative *wahseje-, cf. ON. vaxa vs. vexa, Avestan vax̧aiti 'causes to grow'. It seems to me that hazjan must be identified with Indo-Iranian *sas'instruct'. On *-safjan see Seebold 1970:383, Schrijver 1991:93.

4. Cf. again wahsjan, ON. vaxa vs. vexa. Differently swaran 'to swear', ON. sverja, which belongs to the next category, cf. Latin susurro 'I whisper'.

5. Go. ga-daban 'to be sutitable' (on which see Schrijver 1991:102) may also belong here, cf. German treffend 'apt, apposite'.

6. OE. stæppan 'to step' is probably an original nasal present, cf. wæcnan 'to waken', preterit wōc. Similarly Go. ga-skapjan 'to create', which can hardly be separated from skaban 'to shave'. On wahsjan see above. 
References

Kortlandt, F. 1989. 'The Germanic weak preterit'. Amsterdamer Beitrage zur älteren Germanistik 28:101-109.

Kortlandt, F. 1992. The Germanic fifth class of strong verbs. North-Western European Language Evolution 19:101-107.

Schmid, W.P. 1963. Studien zum baltischen und indogermanischen Verbum. Wiesbaden: Harrassowitz.

Schrijver, P. 1991. The reflexes of the Proto-Indo-European laryngeals in Latin. Amsterdam: Rodopi.

Seebold, E. 1970. Vergleichendes und etymologisches Worterbuch der germanischen starken Verben. The Hague: Mouton.

Stang, C.S. 1942. Das slavische und baltische Verbum. Oslo: Universitetsforlaget.

Stang, C.S. 1966. Vergleichende Grammatik der baltischen Sprachen. Oslo: Universitetsforlaget.

Thurneysen, R. 1946. A grammar of Old Irish. Dublin: DIAS. 